\title{
A Tribute to Professor Jerry Koutts, MD (Syd), BS, FRACP, FRCPA (1944-2013)
}

\author{
Emmanuel J. Favaloro, BSc (Hons), PhD, FFSc (RCPA) ${ }^{1}$ Ken Bradstock, MB BS, PhD ${ }^{1}$ \\ Peter Castaldi, MD (Syd), Hon DU (Paris), FRACP ${ }^{1}$ Graeme J. Stewart, BSC (Med), \\ MB BS, PhD, FRACP, FRCPA ${ }^{1}$ Mark Hertzberg, MB BS, PhD (Syd), FRACP, FRCPA ${ }^{1}$ \\ Warwick J. Benson, MB BS, FRACP, FRCPA ${ }^{1}$ Thomas Exner, PhD $^{1}$ Lesley Survela, MB, ChB, FRCPA ${ }^{1}$ \\ David J. Gottlieb, MB BS, FRACP, FRCPA, MD ${ }^{1}$ Helen Crowther, MB BS (Hons), BSc, FRACP, FRCPA ${ }^{1}$ \\ Leonardo Pasalic, MB BS (Hons), BSc, FRACP, FRCPA ${ }^{1}$ Karen Maddock, Dip Comp Nursing, \\ Grad Cert Oncology Nursing Grad Cert Transfusion Practice ${ }^{1}$
}

${ }^{1}$ Departments of Laboratory and Clinical Haematology and
Immunology, Institute of Clinical Pathology and Medical Research
(ICPMR), Westmead Hospital and University of Sydney, Westmead,
New South Wales, Australia

Semin Thromb Hemost 2014;40:1-4.

Professor Jerry Koutts was a larger-than-life figure in the arena of Australian Haematology, while also enjoying international recognition. He was an innovator in the diagnosis of inherited bleeding disorders and founded (in the early 1980s) the Clinical Haematology Department at Westmead Hospital, in Sydney's then growing western suburbs, and at that time a brand new public teaching hospital planned to be the largest such facility in the Sydney landscape.

Gerasimos Koutsoukos (later Anglicized to Jerry Koutts) was born on November 27, 1944, the third son of Greek migrant parents, George Koutsoukos and his wife Aspasia (nee Delaportas), from Ithaca and Kastellorizo.

He excelled at his Leaving Certificate at Newcastle Boys High; and despite his father's death in Jerry's final year of school, his family were able to support him to study medicine at the University of Sydney. He graduated with honors in 1968.

He then became a resident medical officer at Royal Prince Alfred Hospital in Sydney, then the major teaching hospital of Sydney University. Here, his outgoing personality and sharp mind ensured success in a challenging intellectual environment. He specialized in internal medicine, became a fellow of the Royal Australasian College of Physicians, and was attracted by the newly emerging field of hematology. He met Ann Milne through friends and they were married in 1972.

Jerry joined Prof. Barry Firkin at Monash Medical School in the Alfred Hospital in Melbourne in the early 1970s. Firkin was a beacon to young physicians interested in research, and Koutts had his baptism into a lifelong interest in bleeding and clotting disorders. He wrote an acclaimed MD thesis on aspects of inherited bleeding disorders and published his
Address for correspondence

Emmanuel J. Favaloro, Department of Haematology, Institute of Clinical Pathology and Medical Research (ICPMR), Pathology West, Westmead Hospital, Westmead, NSW 2145, Australia (e-mail: emmanuel.favaloro@health.nsw.gov.au).

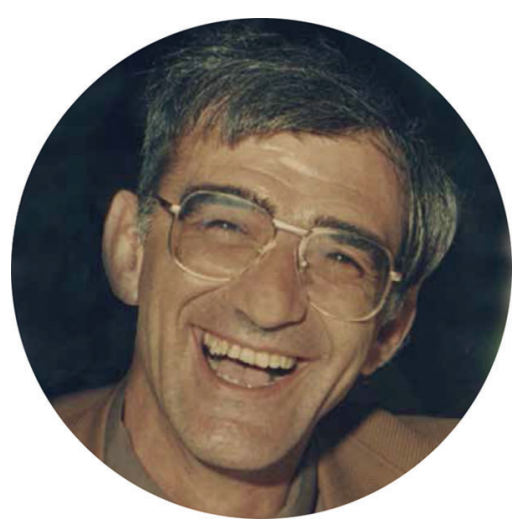

Prof. Jerry Koutts, MD (Syd), BS, FRACP, FRCPA (1944-2013).

first series of hemostasis-related papers, ${ }^{1-6}$ at a time when there was a startling burst of knowledge on these problems. All these articles were related to testing for von Willebrand factor (VWF), von Willebrand disease (VWD), and factor VIII, as well as their relationships, and this "triad of hemostasis" was to set the scene for his lifelong passion in this field. Of special note, Jerry was very much involved in the foundation work that eventually established the use of ristocetin to assist in the diagnosis of VWD. Indeed, the Firkin laboratory was a pioneer of such work, ${ }^{7}$ and one assay that developed from this work, the VWF ristocetin cofactor assay (VWF:RCo), remains even today the most widely used VWF functional assay worldwide for the diagnosis and management of VWD. ${ }^{8}$

Jerry's time in Melbourne was followed by postdoctoral experience in coagulation scientific research in Paris at the Bicetre Institute, and later at the Scripps Clinic in LA Jolla,
Issue Theme Hot Topics V; Guest Editor, Emmanuel J. Favaloro, PhD, FFSC (RCPA).
Copyright (C) 2014 by Thieme Medical Publishers, Inc., 333 Seventh Avenue, New York, NY 10001, USA. Tel: +1(212) 584-4662.
DOI http://dx.doi.org/ 10.1055/s-0033-1364205. ISSN 0094-6176. 
California, and this work also lead to several publications with several overseas mentors. ${ }^{9-12}$ Additional publications related to his primary interest of the VWF-VWD-FVIII triad also ensured around this time, as well as collaborations with other leading Australian hematology-based researchers. ${ }^{11-21}$

Enthused with fresh ideas from the overseas centers of excellence and from successful local Australian collaborations, he returned to Australia in 1980 and made the pivotal career decision to accept a position as a staff physician at the newly established Sydney University teaching hospital at Westmead, which had opened its doors to patients only 18 months previously. There was little in the way of specialist medical care in the area at the time, and Jerry established the Clinical Haematology Department, which provided care for bleeding and clotting disorders, as well as for blood and bone marrow cancers, including the bone marrow transplant service, later to be headed by one of us (K.B.). The next 5 years saw continued collaboration with many other Australian hematology-based researchers, ${ }^{22-36}$ the establishment of diagnostic facilities for inherited bleeding disorders at the Institute of Clinical Pathology and Medical Research (ICPMR), as well the establishment of the "Haemostasis and Thrombosis Research Unit." To help establish this unit, Jerry acquired an emerging young scientist (T.E.) from the "competing" innercity public (Sydney University teaching) hospital, Royal Prince Alfred Hospital, then the major center of Sydney Haematology practice, and set him up as the scientific head of the Westmead haemostasis laboratory.

Another one of us (E.J.F.) was completing a $\mathrm{PhD}$ in the field of leukemia research in 1988, under the mentorship of other coauthors (K.B. and P.C.) to this In Memoriam piece. Jerry always had something of a maverick nature and could always see far outside the box. Despite having absolutely no experience in the field of hemostasis, an appointment as a scientist within the hemostasis section ensued (for E.J.F.), and this was set to create a very successful hemostasis unit, with several hundred articles being published by the small unit in the following quarter century. It is notable that the first few publications came soon after the appointment and were collaborative efforts between the hemostasis and leukemia sections of the department. ${ }^{37,38}$ Nevertheless, Jerry's primary interest was the field of bleeding disorders, notably VWD, and the more complete transition from leukemia to hemostasis for the lead author (E.J.F.) emerged soon after. ${ }^{39-42}$

It is perhaps fitting that some 2 decades later, the final publication listed in PubMed for Jerry was also on VWD diagnosis, describing a novel method for identifying both VWF antigen (VWF:Ag) and collagen binding (VWF:CB) by flow cytometry. ${ }^{43}$ It is also relevant to note here that Jerry penned a very well written historical VWD piece for Seminars in Thrombosis $\mathcal{E}$ Hemostasis in 2006, ${ }^{44}$ which he dedicated to two of his own mentors, Barry Firkin (1930-2001) and Ted Zimmerman (1937-1988). Jerry's clinical and research interest was certainly not restricted to VWD, or even to hemostasis and thrombosis for that matter. However, of the 86 publications attributed to him on PubMed, nearly three-quarters were related to hemostasis and thrombosis, and well more than $50 \%$ of these dealt with the VWF-VWD-FVIII hemostasis triad, clearly establishing this area of interest as that most close to his heart.

As well as being an astute, compassionate, and wise physician and researcher, Jerry provided strong medical leadership, attracting young trainee physicians from around the country and internationally to train in hematology in a robust academic environment. In this capacity he actively encouraged challenging of current dogmas and transmitted his intellectual curiosity to many generations of hematology trainees. Indeed, those who were privileged to have been one of his registrars will remember Jerry as a gifted and dedicated teacher, fierce protector, consummate physician, father figure, and friend, and much richer for having trained under his wing. He was appointed associate professor of medicine in the Faculty of Medicine at the University of Sydney in 1992 in recognition of his teaching and research commitments.

Jerry's interest in diagnostic pathology was striking; he became the head of Laboratory Haematology in 1996, and also the acting director of the ICPMR for several years. In these roles, he was a fearless and tireless advocate for public pathology and health services in the Australian state of New South Wales (NSW).

Jerry Koutts essentially spent his entire senior career of more than 32 years at Westmead, where he built, nurtured, and protected both his department and the ICPMR from various political and administrative assaults. In part, he delayed his retirement to steer the ICPMR through a black period of nonmedically focused management back to medical leadership. Jerry was a passionate man who defended with unreserved passion and determination the people and ideals in which he believed; he was admired widely for it, particularly by those who understood the personal cost he often absorbed in doing so.

Fiona Kwok, a young Westmead consultant in Haematology provided a perspective from younger colleagues when she stated soon after his passing:

Jerry died too young. I have been thinking of him all day. He holds a lifetime of medical experience in the world of hemostasis. More importantly, he really was such a wonderful human being. He has been a caring advocate for registrars in training for many generations of specialists. I have very fond memories of him. I will always think of him as wonderfully outspoken (in a "much too polite" world) yet somehow, in the end, always right and always protective, fatherly, warm and caring.

Outside his direct professional life, Jerry was very engaged in medical politics, serving as chairman of the medical staff council at Westmead Hospital, and as an elected member of the board of the Western Sydney Area Health Service for 4 years.

He was also a founding figure in the formation of the Australasian Association of Consultant Physicians, the political voice of physicians in Australia, and a ministerial appointee on the Medical Services Board of New South Wales. He served as secretary of the Haematology Society of Australia and was a lifelong supporter of that organization. 
Outside of medicine, Jerry was first and foremost a family man, devoted to his extended family. His childhood love of the water led to a lifelong preoccupation with boats, fishing, and later with rowing. The latter culminated in a consuming involvement with the rowing program at Ascham Girls School, which he was instrumental in establishing. Koutts' strong curiosity and passion for new things also led to many and varied travels that enabled him to retain links with his extended Greek family. Jerry was always proud of his Greek heritage, and loved to practice his "Australianized" Greek language skills on unsuspecting locals whenever the opportunity arose.

Jerry is survived by Ann, daughters Nina, Georgia, and Alexandra, granddaughter Elizabeth, and brothers Spiro and Angelo.

Westmead Hospital, the ICPMR, the more recently formed Pathology West, and more specifically the local laboratory and clinical units and departments that he established and fostered, represent a much richer tapestry due to Jerry's involvement. These have also matured into internationally respected institutions in large part due to Jerry's participation. As individuals, we, his close colleagues, and indeed the entire extended hematology community are much poorer, both professionally and personally, for his untimely loss.

He will be dearly missed.

\section{References}

1 Firkin B, Koutts J. Letter: 8-related antigen and von Willebrand factor. Lancet 1974;1(7861):803-804

2 Koutts J, Meyer D, Rickard K, Stott L, Firkin BG. Heterogeneity in biological activity of human factor VIII antibodies. $\mathrm{Br} \mathrm{J}$ Haematol 1975;29(1):99-107

3 Firkin BG, Howard M, Koutts J, Brodie GN, Stott L, Goh A. Letter: Ristocetin-induced platelet aggregation. Blood 1975;46(4): 654-655

4 Koutts J, Gude N, Firkin B. Proceedings: Relationship between factor VIII and von Willebrand's factor in plasma and serum. Thromb Diath Haemorrh 1975;34(2):607

5 Koutts J, Stott L, Firkin BG. Actions of ristocetin on platelets. Am J Hematol 1976;1(3):313-317

6 Koutts J, Gude N, Firkin BG. The dynamic inter-relationship between factor VIII and von Willebrand factor. Thromb Res 1976;8(5):533-541

7 Howard MA, Sawers RJ, Firkin BG. Ristocetin: a means of differentiating von Willebrand's disease into two groups. Blood 1973; 41(5):687-690

8 Favaloro EJ. Von Willebrand disease: local diagnosis and management of a globally distributed bleeding disorder. Semin Thromb Hemost 2011;37(5):440-455

9 Mannucci PM, Meyer D, Ruggeri ZM, Koutts J, Ciavarella N, Lavergne JM. Precipitating antibodies in von Willebrand's disease. Nature 1976;262(5564):141-142

10 Koutts J, Lavergne JM, Meyer D. Immunological evidence that human factor VIII is composed of two linked moieties. $\mathrm{Br} \mathrm{J}$ Haematol 1977;37(3):415-428

11 Koutts J, Walsh PN, Plow EF, Fenton JW II, Bouma BN, Zimmerman TS. Active release of human platelet factor VIII-related antigen by adenosine diphosphate, collagen, and thrombin. J Clin Invest 1978; 62(6):1255-1263

12 Lavergne JM, Meyer D, Koutts J, Larrieu MJ. Isolation of human antibodies to factor VIII. Br J Haematol 1978;40(4):631-641
13 Koutts J, Howard MA, Firkin BG. Factor VIII physiology and pathology in man. Prog Hematol 1979;11:115-145

14 Gan TE, Sawers RJ, Koutts J. Pathogenesis of antibody-induced acquired von Willebrand Syndrome. Am J Hematol 1980;9(4):363-371

15 Salem HH, Koutts J, Firkin BG. Circulating platelet aggregates in ischaemic heart disease and their correlation to platelet life span. Thromb Res 1980;17(5):707-711

16 Howard MA, Perkin J, Koutts J. Factor VIII antigen pre-peak. Lancet 1980;1(8170):715

17 Howard MA, Hau L, Perkin J, Thomas KB, Firkin BG, Koutts J. Causes for the discrepancies in the measurements of factor VIII antigen. Thromb Res 1980;19(1-2):63-72

18 Salem HH, van der Weyden MB, Koutts J, Firkin BG. Leg pain and platelet aggregates in thrombocythemic myeloproliferative disease. JAMA 1980;244(10):1122-1123

19 Howard MA, Perkin J, Koutts J, Firkin BG. Quantitation of binding of factor VIII antigen to concanavalin A. Br J Haematol 1981;47(4): 607-615

20 Salem HH, Whitworth JA, Koutts J, Kincaid-Smith PS, Firkin BG. Hypercoagulation in glomerulonephritis. Br Med J (Clin Res Ed) 1981;282(6282):2083-2085

21 Salem HH, Koutts J, Handley C, van Der Weyden MB, Dudley FJ, Firkin BG. The aggregation of human platelets by ascitic fluid: a possible mechanism for disseminated intravascular coagulation complicating LeVeen shunts. Am J Hematol 1981;11(2):153-157

22 Howard M, Perkin J, Koutts J, Firkin B. Crossed affinity electrophoresis of factor VIII related antigen. Br J Haematol 1982;50(2): 379-380

23 Thomas KB, Howard MA, Koutts J, Firkin BG. Simplified immunoradiometric assay for factor VIII coagulant antigen. $\mathrm{Br} \mathrm{J}$ Haematol 1982;51(1):47-57

24 Gan TE, Sawers RJ, Koutts J. The possibility of an immunologic mechanism responsible for acquired von Willebrand's disease. Blood 1983;61(1):210

25 Crandon AJ, Koutts J. Incidence of post-operative deep vein thrombosis in gynaecological oncology. Aust N Z J Obstet Gynaecol 1983; 23(4):216-219

26 Chong BH, Berndt MC, Koutts J, Castaldi PA. Quinidine-induced thrombocytopenia and leukopenia: demonstration and characterization of distinct antiplatelet and antileukocyte antibodies. Blood 1983;62(6):1218-1223

27 Exner T, Koutts J, Hughes W. Chromogenic microtitre tray assay for plasminogen. Clin Lab Haematol 1984;6(4):379-381

28 Furby FH, Berndt MC, Castaldi PA, Koutts J. Characterization of calcium-dependent binding of endogenous factor VIII/von Willebrand factor to surface activated platelets. Thromb Res 1984; 35(5):501-511

29 Salem HH, Howard MA, Koutts J, Firkin BG. Investigation of a coagulation accelerating factor (CAF) in glomerulonephritis. $\mathrm{Br} \mathrm{J}$ Haematol 1985;59(3):485-496

30 Koutts J. Clinching the diagnosis: assessment of hemostatic function. Pathology 1985;17(4):643-647

31 Exner T, Koutts J. Simple immunochromometric assay for protein $C$ activity. J Lab Clin Med 1986;107(5):405-411

32 Buckley DJ, Barrett AP, Koutts J, Stewart JH. Control of bleeding in severely uremic patients undergoing oral surgery. Oral Surg Oral Med Oral Pathol 1986;61(6):546-549

33 Gottlieb D, Koutts J. Myelodysplasia and retinoid agents. Med J Aust 1986;145(1):56

34 Gottlieb D, Bradstock K, Koutts J, Robertson T, Lee C, Castaldi P. The neurotoxicity of high-dose cytosine arabinoside is age-related. Cancer 1987;60(7):1439-1441

35 Bradstock KF, Koutts J, Stanton A, et al. Improved treatment results for lymphoblastic lymphoma in adolescents and adults using a doxorubicin-based (APO) protocol. Aust N Z J Med 1988;18(4): 563-568

36 Exner T, Koutts J. Autoimmune cardiolipin-binding antibodies in oral anticoagulant patients. Aust N Z J Med 1988;18(5):669-673 
37 Favaloro EJ, Moraitis N, Koutts J, Exner T, Bradstock KF. Endothelial cells and normal circulating haemopoietic cells share a number of surface antigens. Thromb Haemost 1989;61(2):217-224

38 Favaloro EJ, Moraitis N, Bradstock K, Koutts J. Co-expression of haemopoietic antigens on vascular endothelial cells: a detailed phenotypic analysis. Br J Haematol 1990;74(4):385-394

39 Favaloro EJ, Grispo L, Exner T, Koutts J. Development of a simple collagen based ELISA assay aids in the diagnosis of, and permits sensitive discrimination between type I and type II, von Willebrand's disease. Blood Coagul Fibrinolysis 1991;2(2):285-291

40 Favaloro EJ, Bernal-Hoyos E, Exner T, Koutts J. Heparin-induced thrombocytopenia: laboratory investigation and confirmation of diagnosis. Pathology 1992;24(3):177-183
41 Favaloro EJ, Grispo L, Dinale A, Berndt M, Koutts J. von Willebrand's disease: laboratory investigation using an improved functional assay for von Willebrand factor. Pathology 1993;25(2):152-158

42 Favaloro EJ, Dean M, Grispo L, Exner T, Koutts J. von Willebrand's disease: use of collagen binding assay provides potential improvement to laboratory monitoring of desmopressin (DDAVP) therapy. Am J Hematol 1994;45(3):205-211

43 Mina A, Favaloro EJ, Koutts J. A novel flow cytometry single tube bead assay for quantitation of von Willebrand factor antigen and collagen-binding. Thromb Haemost 2012;108(5):999-1005

44 Koutts J. A short history of diagnostic tests for von Willebrand disease: in memory of Barry Firkin (1930 to 2001) and Ted Zimmerman (1937 to 1988). Semin Thromb Hemost 2006;32(5):445-455 